\title{
IbM MANAJEMEN DESA WISATA JIPANGAN
}

\author{
Yohana Ari Ratnaningtyas \\ Fakultas Seni Media Rekam, Institut Seni Indonesia Yogyakarta \\ Email: yohanaarir@gmail.com
}

\begin{abstract}
Abstrak
Sasaran kegiatan ini adalah pengelola desa wisata dan ketua-ketua kelompok yang terkait serta masyarakat sekitar. Setelah peserta mendapatkan materi pelatihan, diharapkan terjadi peningkatan kualitas sumber daya manusia. Dengan demikiantarget yang diharapkan dapat tercapai, yakni:1) meningkatnya kemampuan dan pengetahuan pengelola desa wisata dalam hal manajemen dan pemasaran 2) tersedianya brosur dan company profile sebagai sarana promosi yang berisi informasi tentang produk Desa Wisata Jipangan. Metode yang akan dipakai dalam pencapaian tersebut didahului dengan sosialisasi program untuk menciptakan komunikasi serta membantu meningkatkan pemahaman pengelola tentang pentingnya program pengembangan desa wisata. Dalam proses ini pengelola desa wisata bersama-sama dengan tim pengusul mengidentifikasi dan mengkaji permasalahan, potensi serta peluangnya.Setelah teridentifikasi disusun rencana kegiatan yang konkrit dan realistis dalam bentuk program pelatihan yang bertujuan untuk meningkatkan kemampuan peserta dalam memahami masalah-masalah yang menjadi kendala bagi pengembangan desa wisata dan memberikan pengalaman praktis sesuai dengan perkembangan terkini. Materi yang akan diberikan adalah Seni Pertunjukan, Manajemen Seni, Pelatihan Pariwisata dan Pelatihan Pemasaran. Kemudian diadakan monitoring dan evaluasi yang merupakan suatu proses penilaian, pengkajian dan pemantauan kegiatan ini, baik proses pelaksanaan maupun hasil dan dampaknya yang dilakukan agar sesuai dengan tujuan semula.
\end{abstract}

Kata kunci : manajemen, desa wisata, peningkatan kemampuan

\section{PENDAhuluan}

Upaya pengembangan desa wisata secara terpadu oleh Pemerintah Daerah Kabupaten Bantul merupakan langkah yang strategis dan memiliki prospek yang bagus. Keberhasilan pengembangan Desa Wisata tergantung pada kesan baik dan menyenangkan yang diperoleh wisatawan setelah mengunjungi desa wisata tersebut. Kesan yang baik/menyenangkan akan terbentuk jika para wisatawan merasa mendapatkan apa yang diharapkan, mulai dari kebutuhan akan makan minum, akomodasi serta kebutuhan untuk cinderamata. Sebaliknya jika kesan yang diperoleh wisatawan adalah tidak baik/tidak menyenangkan dapat dipastikan bahwa pengembangan desa wisata tidak akan berhasil yang berarti wisatawan yang datang tidak dapat terpenuhi harapann atau kebutuhannya.

Salah satu desa wisata yang saat ini menjadi perhatian dari Dinas Pariwisata
Kabupaten Bantul adalah Desa Wisata Jipangan. Desa wisata ini berada di dusun Jipangan yang merupakan salah satu dusun di desa Bangunjiwo, Kecamatan Kasihan, Kabupaten Bantul, Propinsi Daerah Istimewa Yogyakarta. Desa Bangunjiwo berjarak sekitar $11 \mathrm{~km}$ ke arah Selatan dari Ibukota Provinsi Daerah Istimewa Yogyakarta, dan $6 \mathrm{~km}$ dari Ibukota Kabupaten Bantul. Daerah ini mudah dicapai oleh semua jenis kendaraan dan telah dihubungkan dengan jalan beraspal serta merupakan desa wisata yang berada disebelah selatan desa wisata Kasongan yang merupakan salah satu pusat industri gerabah yang mulai berkembang di Kabupaten Bantul.

Secara geografis Pedukuhan Jipangan merupakan daerah pegunungan dan berupa hamparan sawah. Luas wilayah Pedukuhan Jipangan $71.489 \mathrm{Ha}$, dengan pekerjaan sebagai petani dan pembuat produk kerajinan bambu sebagai mata pencaharian mereka. Produk kipas bambu sebagai 
kenang-kenangan yang dirintas sejak tahun 1985 hingga sekarang mampu memperbaiki perekonomian dan merupakan penghasilan andalan warga Jipangan.

Desa Kerajinan Jipangan mempunyai rintisan atau gagasan untuk mempromosikan hasil produk industri kerajinan sebagai desa tujuan wisata baik wisatawan domestik maupun wisatawan mancanegara dimana pedukuhanpedukuhan penghasil produk kerajinan tersebut nama KAJIGELEM yangmerupakan singkatan dari:

- Pedukuhan Kasongan, sentra industri kerajinan gerabah

- Pedukuhan Jipangan, sentra industri kerajinan kipas bambu

- Pedukuhan Gendeng, sentra kerajina tatah dan sungging kulit perkamen

- Pedukuhan Lemahdadi, sentra industri kerajinan patung batu

Desa Wisata Jipanganyang berada di dusun Jipangan merupakan salah satu aset desa yang saat ini sedang difokuskan untuk berkembang. Secara administratif dusun ini berbatasan dengan Desa Kasongan di sebelah Utara, Pendowoharjo dan sungai Bedog di sebelah Timur, Kalangandi sebelah Selatan dan Bibis di sebelah Barat. Desa Wisata Jipangan ini masih merupakan desa wisata yang baru karena mulai terbentuk di tahun 2013, atas prakarsa para warga masyarakat dan pemuda yang sadar akan wisata. Hal ini didasarkan pada komitmen dan dorongan yang kuat untuk menggali potensi yang dimiliki dan berupaya untuk meningkatkan pendapatan dan kesejahteraan warga sekitar.

Desa wisata ini mulai dapat perhatian dan dicanangkan sebagai desa wisata pada 15 Maret 2014 dan diprediksi dapat berkembang dengan cepat karena tekat dan komitmen yang kuat dari para penggerak sadar wisata. Desa Wisata Jipangan memiliki beberapa potensi diantaranya suasana khas pedesaan yang masih tradisional lengkap dengan kultur budaya, lokasi desa yang dekat dengan sawah dan sungai sehingga dapat dikembangkan menjadi wisata air dan pertanian. Disamping itu terdapat beberapa pengembangan home industry baik kerajinan maupun kuliner ditambah dengan tekat dan semangat pemuda yang ingin bersama-sama memajukan desanya.

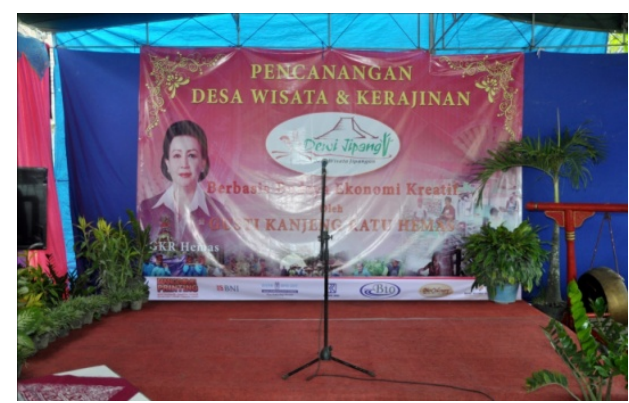

Gambar 1. Peresmian Desa Wisata oleh GKR Hemas

Sampai saat ini Desa Wisata Jipangan telah memiliki beberapa fasilitas diantaranya mushola, area lahan sebagai wahana out bound yang dipakai untuk berbagai permainan air dan darat, lengkap dengan fasilitas kamar kecil, homestay, tempat pelatihan kerajinan dan showroom. Selain kelompok pengrajin kipas bambu “ MAS PANJ" yang menjadi unggulan, Jipangan juga kaya akan atraksi kesenian dan budaya, seperti : jathilan, karawitan, gejok lesung dan sebagainya. Salah satunya adalah kelompok "Kudho Kencono". Disamping dapat menikmati atraksi budaya, wisatawan juga berkesempatan untuk berlatih secara langsung menabuh gamelan maupun gejok lesung, sehingga mereka akan mendapatkan pengalaman yang tak terlupakan berkesenian di Jipangan.

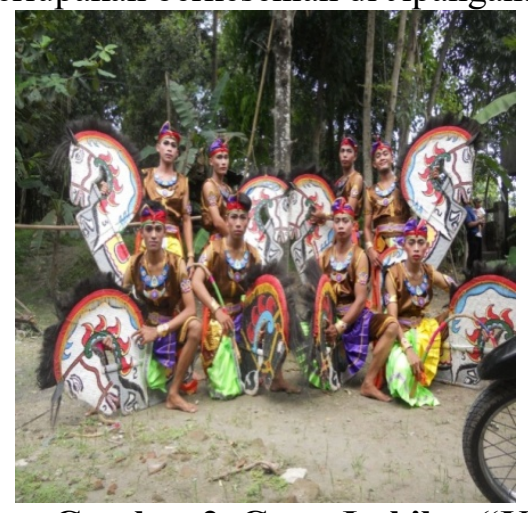

Gambar 2. Grup Jathilan "Kudho Kencono" 
Fasilitas yang ada ini akan terus dikembangkan lagi sehingga dapat memberikan kenyamanan serta kepuasan bagi wisatawan yang datang menikmati suasana pedesaan yang asri. Potensi dan semangat dari pengelola desa wisata ini saja tidak cukup, perlu diimbangi dengan adanya tambahan pengetahuan dan ketrampilan untuk mengelola dan memasarkan desa wisata ini dengan lebih optimal agar terjadi kunjungan wisatawan yang terus meningkat dan selalu diakhiri dengan kepuasan atas penggunaan produk dan jasa layanan dari Desa Wisata Jipangan. Disamping itu masyarakat di desa tersebut juga harus dibina dan disiapkan menjadi warga yang sadar wisata agar bisa menerima kunjungan wisatawan sebagai tamu yang harus dihormati sehingga wisatawan merasa nyaman dan diharapkan menjadi pendukung meningkatkan sumber penghasilan bagi mereka.

Berdasarkan pengamatan lebih lanjut terhadap kondisi internal, ditemukan beberapa permasalahan yang dihadapi antara lain: keterbatasan sumber daya manusia seperti rendahnya jiwa wirausaha, kemampuan dan ketrampilan mengelola yang masih sangat terbatas, kurang berani mengambil tindakan yang dirasa berisiko dan sudah merasa cukup puas dengan yang dijalani dan dicapai. Kondisi tersebut diharapkan segera dapat diminimalkan sehingga pengelolaan desa wisata ini dapat berkembang dengan lebih optimal. Dengan berbagai pelatihan diharapkan mereka dapat segera mengadopsi perkembangan teknologi baru untuk meningkatkan daya saing produk yang dihasilkan.

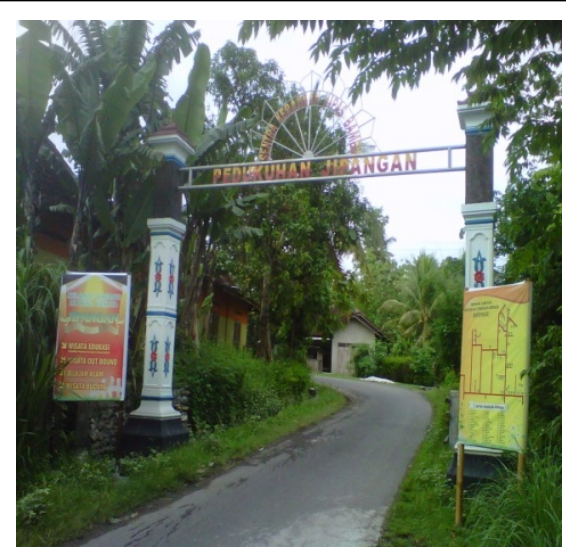

Gambar 3. Gapura Desa Wisata Jipangan

Dengan keterbatasan sumberdaya yang dimiliki, pada umumnya masih lemah dalam hal pengelolaan usaha seperti manajemen usaha masih bersifat tradisional dan kekeluargaan, tidak ada pemisahan antara keuangan keluarga dengan usaha, tidak ada perencanaan menyeluruh atas proses produksi dan pemasaran dan dokumentasi kegiatan yang belum tertata dengan baik. Desa wisata ini juga masih mempunyai berbagai kelemahan dalam hal pemasaran seperti jaringan yang belum luas, belum mempunyai kesempatan untuk mengikuti pameran maupun promosi dan pemasaran yang dilakukan masih bersifat konvensional. Hal ini karena keberadaan sebagai desa wisata masih tergolong baru, sehingga masih sangat dibutuhkan pendampingan, baik material maupun sumber daya manusia yang mengelolanya.

Menurut Australia's Commonwealth Departemen of Tourism (1994) dalam strategi pariwisata pedesaan Australia dikatakan bahwa pengklasifikasian pariwisata pedesaan meliputi; pulau, pantai, pedalaman, desa, semak-semak, dan daerah terpencil. Kategori ini untuk menggabungkan variabel ekologis dan perseptual, khususnya pada pola-pola geografis dan permukiman desa. Sedangkan Lane (1994) mengidentifikasi faktor-faktor yang mempengaruhi keberlangsungan investasi di daerah pedesaan meliputi: nilai keindahan, aset khusus margasatwa, aset kultural, kemudahan untuk mengakses oleh masyarakat, fasilitas olahraga, keterampilan manajemen dan promosi yang efektif. 
Pariwisata dipandang dapat menjadi alat penarik investasi di daerah yang sangat potensial. Jika dibandingkan dengan sektor lain, yakni sektor industri, sektor pertanian dan sektor primer lainnya, pariwisata memiliki banyak keunggulan, diantaranya pengembangan pariwisata merupakan yang paling cepat dapat dilaksanakan, bisa dilaksanakan dengan metode yang paling mudah, dan kendalanya relatif lebih sedikit. Sektor lain akan lebih mudah mendapatkan kendala. Industri pariwisata juga menawarkan cara yang cepat untuk membangun industri pendukung, yakni: hotel, restoran, penyewaan bus wisata, sewa perahu, industri souvenir, dan lainnya (Gunawan dan Ina Herlina, 2000).

Supaya pariwisata dapat berlangsung secara berkelanjutan, maka pelaksanaan pengembangannya harus berpegang pada prinsip-prinsip yaitu menjaga kebebasan, kemandirian, keutuhan bangsa dan wilayah; memupuk rasa cinta tanah air, persatuan, kebhinekaan, pluralisme, dan multikultur; memeratakan dan meningkatkan kesejahteraan masyarakat serta meningkatkan persahabatan antar suku bangsa dan perdamaian (Ardika, 2007). Dalam kaitannya dengan pengembangan pariwisata ini, Pinata \& Diarta (2009), menyatakan bahwa untuk mengembangkan sebuah kawasan pedesaan menjadi kawasan pariwisata yang memiliki daya tarik, diperlukan beberapa tahapan pendekatan, yakni pertama tahap perencanaan yang terdiri atas dua bagian yaitu perencanaan secara individu dan kolektif. Tahap ini harus dimulai dengan membangkitkan kesadaran individu penduduk lokal dan kemudian pengadopsian secara kolektif peluang pemanfaatan sumberdaya lokal dalam perencanaan sosial ekonomi. Kemudian penguatan sistem sosial, pada tahap ini mulai dibangun kemitraan antara komunitas lokal dengan lembaga pariwisata formal untuk menjamin keberlanjutan atraksi pariwisata kawasan. Terakhir, implementasi rencana pengembangan pariwisata perdesaan, yang dicirikan oleh telah berlangsungnya kegiatan pariwisata pedesaan

\section{METODE KEGIATAN}

Sasaran kegiatan pengembangan desa wisata ini adalah pengelola desa wisata dan ketua kelompok yang terkait dengan desa wisata. Setelah peserta mendapatkan materi pelatihan, diharapkan mereka dapat menjelaskannya kembali kepada rekan sekerja mereka atau kepada bawahan mereka sehingga bisa terjadi peningkatan kualitas sunber daya manusia di seluruh desa wisata. Dengan begitu target yang diharapkan dapat tercapai, yakni meningkatnya kemampuan dan pengetahuan pengelola desa wisata dalam hal manajemen dan pemasaran dan membentuk masyarakat yang sadar wisata serta tersedianya brosur dan company profile sebagai sarana promosi yang berisi informasi tentang produk Desa Wisata Jipangan.

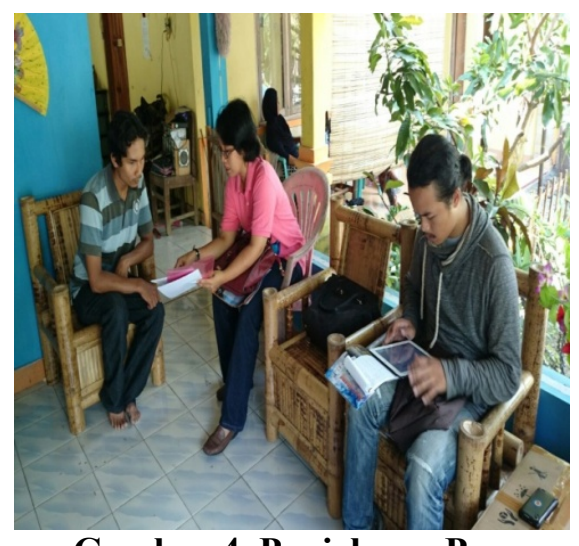

Gambar 4. Penjelasan Program

Dengan mengetahui permasalahan yang dihadapi, maka ditawarkan solusi untuk meningkatkan kinerja mereka dengan cara mengembangkan desa wisata supaya dapat lebih berdaya dan selanjutnya dapat berperan lebih besar bagi pengembangan perekonomian masyarakat. Adapun metode yang diterapkan adalah yang pertama sosialisasi program kegiatan untuk menciptakan komunikasi serta membantu untuk meningkatkan pemahaman pengelola desa wisata dan pihak terkait tentang pentingnya program pengembangan desa wisata untuk mendukung pengembangan pariwisata dan memajukan ekonomi masyarakat. Maksud program pengabdian ini adalah untuk meningkatkan kemampuan 
pengelola desa wisata dalam memahami manajemen dan pemasaran. Dalam proses ini pengelola desa wisata bersama-sama dengan tim mengidentifikasi dan mengkaji permasalahan, potensi serta peluang. Setelah teridentifikasi segala potensi dan permasalahan yang dihadapinya, selanjutnya pengelola desa wisata bersama tim menyusun rencana kegiatan yang konkrit dan realistis. Implementasi rencana kegiatan dengan melakukan pelatihan yang ditujukan untuk meningkatkan kemampuan peserta pelatihan dalam memahami masalah-masalah yang menjadi kendala bagi pengembangan desa wisata dan memberikan pengalaman praktis sesuai dengan perkembangan terkini.

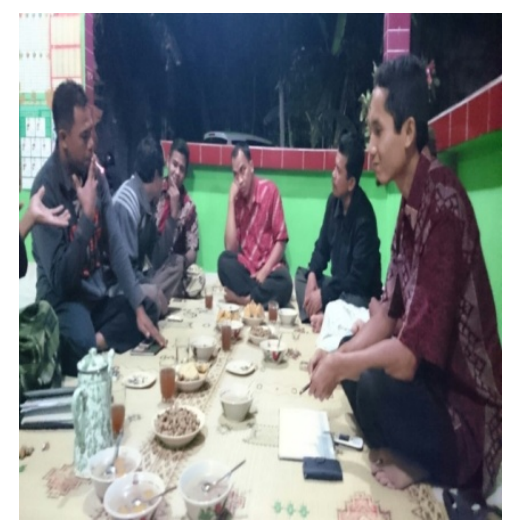

\section{Gambar 5. Pertemuan Pokdarwis}

Materi yang akan diberikan pada peserta antara lain: Seni Pertunjukan, Manajemen Seni, dan Pelatihan Pariwisata. Masing-masing diberikan dalam 8 kali pertemuan, dengan harapan peserta telah memperoleh pemahaman yang cukup untuk mengelola desa wisata dan kelompok secara lebih baik dan profesional. Setelah selesai pelatihan dilakukan monitoring dan evaluasi partisipatif yang merupakan suatu proses penilaian, pengkajian dan pemantauan kegiatan ini, baik proses pelaksanaan maupun hasil dan dampaknya yang dilakukan agar sesuai dengan tujuan semula.

\section{HASIL DAN PEMBAHASAN}

Sebelum melaksanakan pengabdian pada masyarakat dilakukan terlebih dahulu surve ke desa wisata Jipangan untuk mengetahui berbagai potensi yang ada di desa tersebut, dengan melakukan kunjungan ke pengelola desa wisata. Kemudian diadakan sosialisasi dengan pengurus desa wisata, pengelola grup kesenian dan kerajinan serta karang taruna untuk memberikan penjelasan program pengabdian yang akan dilaksanakan dan teknik pelaksanaan di lapangan. Respon dari desa sangat positif terbukti dengan diskusi dan kesepakatan terkait dengan pelaksanaan program ini. Disamping itu pengurus sangat antusias dan kooperatif terhadap rencana yang disampaikan. Pada saat pembukaan program pelatihan dihadiri oleh pengurus dan tokoh masyarakat setempat dan perwakilan dari Dinas Pariwisata Kabupaten Bantul.

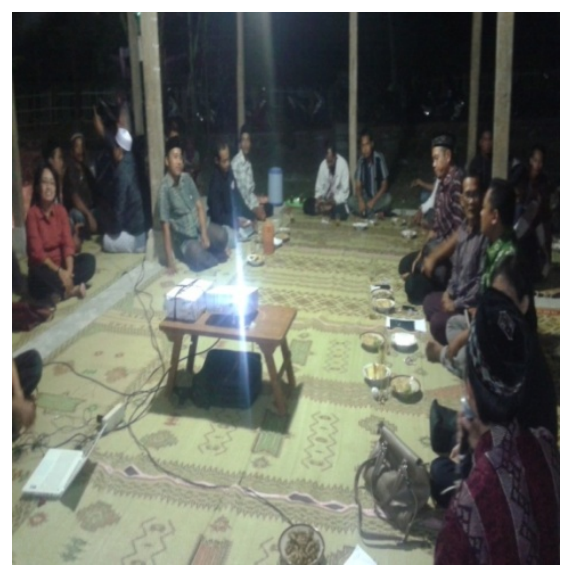

\section{Gambar 6. Pertemuan dengan Dinas Pariwisata Bantul}

Pelatihan yang pertama adalah pelatihan manajemen yang bertujuan untuk memperbaiki pengelolaan desa wisata dengan materi yang diajarkan meliputi manajemen keuangan, pemasaran, sumber daya manusia dan cara berkomunikasi yang efektif. Masyarakat sangat terbuka dalam menerima masukan dari tim. Dalam pelatihan manajemen tampak antusiasme dari pokdarwis dan pengurus untuk mempelajari pengelolaan manajerial yang baik dan benar untuk kemajuan desa wisata mereka. Selama ini manajemen yang dilaksanakan belum tertata dengan baik, sehingga ada beberapa pos dana dan pengelolaan yang tidak seimbang. Peserta yang hadir sebanyak 25 orang menanyakan berbagai masalah yang terkait dengan manajemen agar bisa dipergunakan untuk memperbaiki dan mengembangkan desa 
wisata ini. Dengan dilaksanakannya pelatihan ini, pengelola menjadi mampu memaksimalkan dana dalam pos-pos yang telah ada. Kemajuan dalam berkomunikasi juga menjadi catatan penting dalam pelaksanaan pelatihan ini, sehingga diharapkan wisatawan yang akan datang berkunjung mendapatkan suasana kekeluargaan yang baik dan natural.

Kemudian diadakan pelatihan seni pertunjukan diikuti 15 orang peserta yang meliputi pengenalan ragam gerak tari Jathilan, gerakan pembukaan khususnya penambahan dalam ragam gerak tayungan prajuritan. Juga dilatih pengembangan gerak sembahan sila dan sembahan jengkeng, diikuti dengan sikap menari yang harus dedeg atau trap njoged gaya Yogyakarta, pengenalan greged, sengguh, ora mingkuh (prinsip joged mataram). Dilanjutkan dengan pengembangankomposisi gerak rampak, penambahan gerak rampak simultan pada gerak kiprah dan pengembangan perangan. Lalu diadakan pelatihan keluwesan dan struktur tari yang jelas. Kesulitan menari dipecahkan bersama, penari sudah menguasai dedeg menari, greget, sengguh, ora mingkuh. Diadakan run through menari jathilan utuh, dari sembahan pembuka hingga sembahan penutup. Pada program pelatihan seni pertunjukan yang dilaksanakan di kelompok kesenian jathilan, juga mendapatkan respon yang positif. Gerakan-gerakan tambahan yang dilatihkan oleh tim, diterima dan dipelajari dengan baik oleh anggota kelompok kesenian Jathilan.

Pelatihan yang terakhir dilakukan adalah pelatihan pariwisata dengan jumlah peserta 20 orang. Materi yang disampaikan adalah pengantar pariwisata, pengenalan dan materi tentang industry pariwisata, sarana dan prasarana wisata, obyek dan atraksi wisata, manajemen dan pemasaran pariwisata serta dikenalkan tentang seluk beluk desa wisata beserta cara pengembangannya. Pada pelatihan pariwisata, tampak antusiasme masyarakat dalam menerima materi untuk pengembangan potensi kepariwisataan yang telah ada di desa wisata Jipangan. Kemudian muncul semangat dan ide-ide untuk memperbaiki objek dan atraksi wisata (kerajinan, wisata alam, serta wisata air). Tak dipungkiri ada beberapa kendala dalam pengembangan tersebut, misalnya limbah pabrik gula yang secara berkala dibuang di kawasan sungai bedog yang melintasi desa wisata, kemudian banyaknya limbah bambu yang berasal dari sisa kerajinan kipas. Dalam pelatihan ini muncul ide untuk menyiasati dan memanfaatkan limbah tersebut, di kesempatan mendatang mengharapkan akan ada pelatihan lanjutan membuat kerajinan limbah bambu (bonggol bambu) untuk dijadikan kerajinan dan layak jual, sehingga menjadi tambahan potensi wisata.

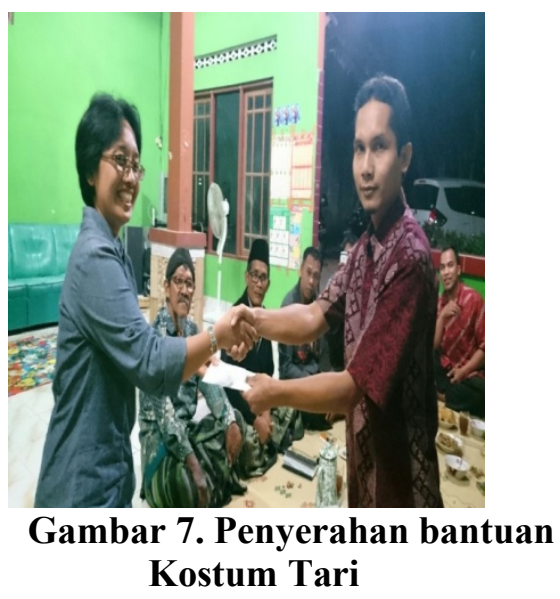

Selain ketiga pelatihan seperti yang disebutkan diatas, desa wisata ini juga dibuatkan brosur dan company profile yang berisi berbagai obyek dan daya tarik wisata yang bisa dinikmati di desa wisata Jipangan. Dengan adanya pembuatan brosur dan company profile ini dimaksudkan untuk membantu memperluas pemasaran sehingga diharapkan desa wisata Jipangan dapat semakin dikenal wisatawan baik wisatawan nusantara maupun wisatawan mancanegara. Disamping itu juga diserahkan bantuan berupa kostum baru jathilan yang merupakan satu paket lengkap yang terdiri dari baju, jarik dan berbagai asesoris pendukung. Pemberian bantuan konstum untuk kelompok jathilan Kudho Kencono merupakan suatu hal yang sangat berarti, karena ketika mereka akan melakukan pementasan tidak perlu lagi keluar biaya untuk menyewa kostum jathilan, dan ini 
cukup membantu dalam biaya pengelolaan desa wisata Jipangan. Penutupan pelatihan dan penyerahan bantuan brosur, company profile dan kostum jathilan dihadiri oleh Dinas Pariwisata Bantul, pengeloa desa wisata dan pengurus kelompok kesenian serta warga masyarakat setempat.

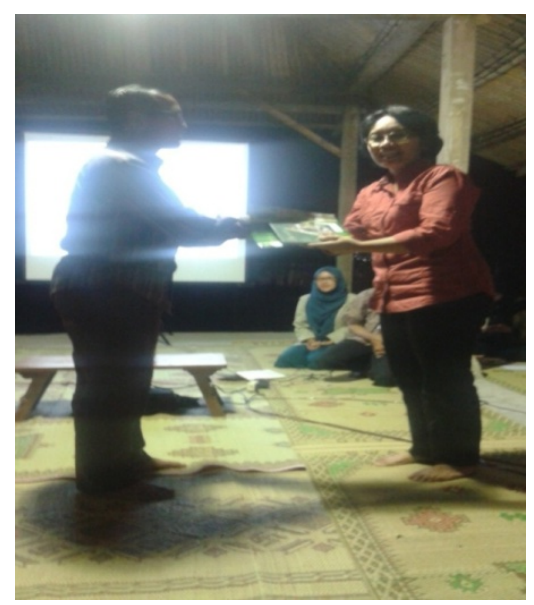

\section{Gambar 8. Penyerahan CD company profile dan brosur}

\section{SIMPULAN DAN REKOMENDASI}

Dari program pengabdian masyarakat berupa pelatihan manajemen, seni pertunjukan, dan pariwisata seperti telah disebutkan di atas, dapat ditarik kesimpulan bahwa sebagai desa wisata yang masih terbilang baru Jipangan menyimpan banyak potensi yang harus terus dikembangkan. Masyarakat dengan terbuka mau memperbaiki diri dengan latihan dan tambahan pengetahuan yang didapat sehingga diharapakan desa wisata ini akan semakin maju dan berkembang serta dikenal oleh masyarakat luas.

Perubahan pola pemasaran Kegiatan yang menjadi lebih agresif daripada sebelumnya diharapkan dapat semakin menarik banyak wisatawan untuk berkunjung dan menginap di desa wisata Jipangan. Banyaknya potensi wisata yang mulai dikembangkan oleh masyarakat desa Wisata Jipangan pada saat ini, diharapkan pada tahun-tahun mendatang akan menjadi daya tarik tersendiri sehingga desa Wisata
Jipangan dapat menjadi salah satu desa wisata unggulan di Kabupaten Bantul.

Agar dapat menjadi desa wisata yang lebih berkembang perlu dipersiapkan fasilitas pendukung yang lebih baik serta terlaksananya sapta pesona dalam kehidupan masyarakat di desa wisata Jipangan serta memasarkannya di luar kota Yogyakarta sehingga pangsa pasarnya terbuka lebih luas. Disamping itu diharapkan keterlibatan pemerintah lebih lanjut seperti adanya dukungan fasilitas maupun pendanaan bagi pemasaran dan pengembangan desa wisata Jipangan ini.

\section{UCAPAN TERIMA KASIH}

1. Direktorat Riset dan Pengabdian Kepada Masyarakat, Direktorat Jenderal Penguatan Riset dan Pengembangan, Kementerian Riset, Teknologi dan Pendidikan Tinggi Republik Indonesia.

2. Dinas Pariwisata Kabupaten Bantul, Daerah Istimewa Yogyakarta.

3. Pengelola Desa Wisata Jipangan Kabupaten Bantul, Daerah Istimewa Yogyakarta.

\section{DAFTAR PUSTAKA}

Ardika, I Gde. (2007). Paradigma Baru Kepariwisataan, Makalah dalam Konferensi Pariwisata Indonesia 2020, Yogyakarta, 22 Agustus 2007.

Australia's Commonwealth Departement of Tourism, (1994). National Rural Tourism Strategy, Canbera: Australia's Commonwealth Departement of Tourism.

Cawley, M., \& Gillmor, D. A. (2008). Integrated rural tourism:Concepts and Practice. Annals of tourism research, 35(2), 316-337.

Clarke, J. (1999). Marketing structures for farm tourism: beyond the individual provider of rural tourism. Journal of Sustainable Tourism, 7(1), 26-47. 
Clarke, J. (2005). Effective marketing for rural tourism. Rural tourism and sustainable business, $26,87$.

Drăgulănescu, I. V., \& Druţu, M. (2012). Rural tourism for local economic development. International Journal of Academic Research in Accounting, Finance and Management Sciences, 2(1), 196-203.

Gunawan, Myra P. dan Ina Herlina. (2000). Garis Besar Perencanaan Pembangunan dan Pemasaran Pariwisata Di Tingkat Lokal Dan Wilayah. Bandung. Pusat Penelitian Kepariwisataan ITB.

Lane, B. (1994). Sustainable rural tourism strategies: A tool for development and conservation. Journal of sustainable tourism, 2(1-2), 102-111.
Lane, B. (2009). Rural tourism: An overview. The SAGE handbook of tourism studies, 354-370.

Laporan Tahunan Desa Bangunjiwo. 2016.

Nugroho, Iwan. (2011). Ekowisata dan Pembangunan Berkelanjutan. Yogyakarta. Pustaka Pelajar.

Pangabean, Riana. (2004). Membangun Paradigma Baru Dalam Mengembangkan DESA WISATA. Jakarta.

Pemerintah Desa Kebonagung. (2000). Penyusunan perencanaan pengembangan kawasan desa wisata Kebonagung. Bantul.

Pitana, I Gde \& Diarta, I Ketut Surya. (2009). Pengantar Ilmu Pariwisata. Yogyakarta. Andi Publishing.

Profil Desa Wisata Jipangan. 2016.

$\mathrm{Su}$, B. (2011). Rural tourism in China. Tourism Management, 32(6), 1438-1441. 